\title{
Cervical Cancer cT1b TNM Finding v8
}

National Cancer Institute

\section{Source}

National Cancer Institute. Cervical Cancer CT 1b TNM Finding v8. NCI Thesaurus. Code C139691.

Cervical cancer with clinically visible lesion confined to the cervix. (from AJCC 8th Ed.) 